\title{
SUBSTITUSI PENGGUNAAN NAUPLIUS ARTEMIA DENGAN MICROWORM (Panagrellus redivivus) TERHADAP KELANGSUNGAN HIDUP LARVA IKAN CUPANG (Betta sp.)
}

\section{SUBSTITUTION OF NAUPLIUS ARTEMIA WITH MICROWORM (Panagrellus}

redivivus) TOWARDS THE SURVIVAL OF BETTA FISH LARVAE (Betta sp.)

\author{
Epram $^{1)}$, Ediyanto $^{1)}$, Yudha Lestira Dhewantara $^{1 *}$ \\ ${ }^{1}$ Fakultas Perikanan dan Ilmu Kelautan, Universitas Satya Negara Indonesia \\ * Korespondensi:yudhalestira@gmail.com
}

\begin{abstract}
ABSTRAK
Ikan Cupang adalah salah satu jenis ikan hias yang mempunyai nilai ekonomis tinggi dan banyak terdapat di pasaran lokal dan mancanegara. Microworm merupakan pakan hidup larva karena ukurannya yang kecil $(0,180-0,5 \mathrm{~mm})$. Nauplius Artemia memiliki nilai gizi tinggi, ukuran relatif kecil $(0,4-0,6 \mathrm{~mm})$. Substitusi Nauplius Artemia dengan Microworm diharapkan memiliki dampak yang signifikan terhadap pertumbuhan dan kelangsungan hidup betta sp. Analisis yang digunakan yakni analisis RAL satu faktor terhadap pengamatan dari 5 perlakuan dan 5 ulangan. Perlakuan A : 100\%

Microworm (Panagrellus redivivus); Perlakuan B : 75\% Microworm (Panagrellus redivivus) dan 25\% Nauplius Artemia; Perlakuan C :50\% Microworm (Panagrellus redivivus) dan 50\% Nauplius Artemia; Perlakuan D : 25\% Microworm (Panagrellus redivivus) dan 75\% Nauplius Artemia; Perlakuan E :100\% Nauplius Artemia. Hasil penelitian menunjukan pemberian Microworm dan Nauplius Artemia dapat meningkatkan pertumbuhan bobot dan pertumbuhan panjang larva ikan Cupang. Tingkat kelangsungan hidup tertinggi diperoleh pada perlakuan E yang diberi pakan Nauplius Artemia (100\%) sebesar 76,25\%, dan tingkat kelangsungan hidup terendah terdapat pada perlakuan A yang diberi pakan Microworm 100\% sebesar 56,25\%. Perlakuan E diberi Nauplius Artemia (100\%) merupakan pakan terbaik dengan nilai sebesar 76,25\% namun dengan keuntungan yang lebih kecil (Rp.17.543,-) dibandingkan dengan perlakuan A yang diberi pakan Microworm 100\% dengan keuntungan (Rp.105.583,-).
\end{abstract}

KATA KUNCI: ikan cupang, kelangsungan hidup, microworm, Panagrellus redivivus, nauplius artemia

\begin{abstract}
Betta fish are one type of ornamental fish that has high economic value and is widely available in the local market and abroad. Walter is one of a live feed of the larvae due to its small size (of 0.180-0.5 mm). Nauplius Artemia have nutritional value is high, relatively small size $(0.4-0.6 \mathrm{~mm})$. Substitution of Nauplius Artemia with Walter is expected to have a significant impact on the growth and survival of Betta sp. The analysis used the analysis $\mathrm{R} A L$ one factor against observations of 5 treatments and 5 replications. Treatment A: 100\% Panagrellus redivivus; Treatment B : 75\% Panagrellus redivivus and 25\% Nauplius Artemia; Treatment C:50\% Panagrellus redivivus and 50\% Nauplius Artemia; Treatment D : 25\% Panagrellus redivivus and 75\% Nauplius of Artemia; Treatment E :100\% Artemia. The results showed the granting of Walter and Nauplius Artemia can increase the growth of the weight and length growth of the larvae of Betta fish. The highest survival rate was obtained in treatment E feeding Nauplius Artemia (100\%) with a value of 76,25\%, and the survival rate is lowest in the treatment of $A$ feeding Fry $100 \%$ with a value of $56,25 \%$. Treatment of E given feed Nauplius Artemia (100\%) is the best feed for the survival of the larvae of Betta fish with a value of $76,25 \%$ but with the cost of feed is high impact on a smaller profit (Rp. 17.543,-) compared with the treatment of A feeding Fry with 100\% profit (Rp.105.583,-).
\end{abstract}

KEYWORDS: betta fish, microworm, Panagrellus redivivus, nauplius artemia, survival 


\section{PENDAHULUAN}

Ikan Cupang (Betta sp) adalah salah satu jenis ikan hias yang mempunyai nilai ekonomis tinggi dan banyak terdapat di pasaran lokal. Harga pasaran di dalam negeri ikan Cupang jantan berkisar Rp. 5.000 sampai dengan Rp. 1.000.000 per ekor, harga tergantung kualitas corak warna dan tubuh ikan. Selain memilki nilai ekonomis ikan Cupang (Betta sp) mudah untuk pemeliharaanya. Anak-anak orang dewasa hingga kalangan beberapa artis Indonesia menggemari ikan Cupang (Betta sp).

Kegiatan budidaya perlu ditunjang dengan pengembangan usaha pembenihan ikan, usaha ini diharapkan mampu menyediaan benih yang memadai dan berkualitas. Usaha pembenihan memerlukan pakan alami sebagai pengganti pakan komersil yang notabene harga dari pakan komersil yang mahal.

Pakan alami merupakan pakan yang sangat cocok untuk pertumbuhan benih ikan karena kandungan nutrisi yang dimiliki seimbang, sesuai dengan bukaan mulut benih dan sistem pencernaannya. Pakan alami memiliki banyak kelebihan dibanding pakan buatan seperti ukuran yang sesuai dengan bukaan mulut, warna yang menarik, kandungan nutrisi yang tinggi, dan yang tidak dimiliki oleh pakan buatan adalah pakan alami dapat bergerak aktif sehingga menarik bagi ikan.

Menurut Djarijah (1996), pakan alami adalah makanan yang keberadaanya tersedia di alam. Sifat pakan alami yang mudah dicerna sesuai sebagai pakan karena benih ikan Cupang memiliki alat pencernaan yang belum sempurna.

Salah satu faktor utama yang sangat menunjang keberhasilan usaha budidaya pembenihan ikan Cupang (Betta sp.) adalah pakan. Tubifex sp. menjadi salah satu pakan alami terbaik, terhadap pertumbuhan, pertambahan panjang maupun peningkatan berat dan tingkat kelangsungan hidup larva ikan Cupang (Betta sp.). (Simbolon dan
Usman, 2018). Pembudidaya kesulitan memperoleh Tubifex sp. dari alam maupun pengepul karena keterbatasan hasil tangkapan di alam, terutama pada musim penghujan.

Microworm (Panagrellus redivivus) merupakan salah satu hewan renik dari phylum nematoda. Di kalangan penghobi ikan hias lebih dikenal dengan sebutan microworm atau Cacing renik. Keunggulan Microworm (Panagrellus redivinus) menurut Sorgeloos \& Lavens (1996), merupakan pakan hidup larva karena ukurannya yang kecil $(0,180-0,5 \mathrm{~mm})$, memiliki kandungan protein $48.3 \%$.

Nauplius Artemia yang merupakan zooplankton dari anggota krustacea. Keunggulan Nauplius Artemia adalah memiliki nilai kandungan protein sebesar 40 $60 \%$, dapat menetas dengan cepat, ukuran relatif kecil, dan pergerakan lambat serta dapat hidup pada kepadatan tinggi. Susanto et al (2000) menyatakan bahwa ukuran Nauplius Artemia 0,4-0,6 mm.

Biaya pakan yang sangat mahal untuk kebutuhan pertumbuhan dan kelangsungan hidup larva ikan Cupang (Betta sp.) dengan nutrisi yang tinggi untuk menghasilkan pakan hidup Nauplius Artemia. Oleh karena itu, pakan alternatif sangat dibutuhkan untuk menekan biaya pakan dan meningkatkan keuntungan.

Berdasarkan hal-hal tersebut, perlu dilakukan penelitian untuk mengetahui kualitas ikan yang dihasilkan oleh kedua jenis pakan alami yang memiliki nutrisi pakan yang tinggi. Perlu adanya upaya untuk mendukung perkembangan Microworm (Panagrellus redivivus) yang dapat menjadi pakan alami esensial sehingga dapat mengurangi ketergantungan terhadap impor Nauplius Artemia yang harganya relatif mahal.

Penelitian ini bertujuan untuk mengetahui pertumbuhan pada larva ikan Cupang yang disubstitusikan penggunaan Nauplius Artemia dengan Microworm (Panagrellus redivivus). Mengetahui kelangsungan hidup pada larva ikan Cupang yang disubstitusikan penggunaan Nauplius 
Artemia dengan Microworm (Panagrellus redivivus). Mengetahui informasi dari 2 jenis pakan alami yang terbaik antara Microworm (Panagrellus redivivus) dan Nauplius Artemia ditinjau dari analisis ekonomi.

\section{METODE PENELITIAN}

\section{Waktu dan Tempat}

Penelitian dilaksanakan pada bulan Juni 2019 sampai dengan Agustus 2021. Lokasi penelitian dilokasi Epram Farm, dengan Nomor Induk Berusaha (NIB) 1251000520968). Kp. Pulo Nyamuk RT/RW 02/06 No.84 Kel. Parung Serab, Kota Tangerang, Ciledug - Banten 15153. Laboratorium Akuakultur, Fakultas Perikanan dan Ilmu Kelautan, Universitas Satya Negara Indonesia.

\section{Alat dan Bahan}

Alat - alat yang digunakan adalah Aerator, ember diameter $30 \mathrm{~cm}$, timbangan 0,001g, botol plastik,toples plastik, gelas takar, soliter, kertas milimeter, saringan, refraktor meter, Dissolved oxygen meter \& suhu, termometer ruangan, $\mathrm{pH}$ meter, sendok takar, test $\mathrm{NO}_{3}$, pipet, meja, buku, pulpen, kamera hp, laptop. Sementara bahan-bahan yang digunakan siste Nauplius Artemia, inoculan Microworm (Panagrellus redivivus), oatmeal instant, ragi roti, larva ikan Cupang (Betta sp.), garam ikan, air, es batu.

\section{Analisis Data}

Desain penelitian yang digunakan adalah RAL (Rancangan Acak Lengkap) satu faktor. Data yang diperoleh di uji sidik ragam (ANOVA). Apabila hasil yang diperoleh signifikan maka dilanjutkan dengan uji Duncan untuk mengetahui perbedaan antar perlakuan dan uji lanjut dengan menggunakan software SPSS versi 26.
Selanjutnya data akan disajikan dalam bentuk Tabel.

$$
Y_{i j}=\mu+{ }_{T_{i}}+\varepsilon_{i j}
$$

Keterangan:

$Y_{\mathrm{ij}} \quad$ : Nilai pengantar dari nilai ke-I sampai ke-j

$\begin{array}{ll}\mu & : \text { Nilai tengah umum } \\ \mathrm{T}_{\mathrm{i}} & : \text { Tambahan akibat pengaruh } \\ & \text { perlakuan ke-i }\end{array}$

$\varepsilon_{\mathrm{ij}} \quad:$ Tambahan akibat acak galat percobaan dari perlakuan ke-1 pada ulangan ke-j

i : Perlakuan

j : Ulangan

Penelitian ini menggunakan 5 perlakuan dan 5 ulangan dengan dosis 30\% (Irama, 2017). Dosis terbaik Microworm (Panagrellus redivivus) terhadap pertumbuhan dan kelangsungan hidup larva ikan cupang (Betta splendens) Perlakuan yang diterapkan dalam penelitian ini adalah sebagai berikut:

Perlakuan A : 100\% Pakan alami Microworm (Panagrellus redivivus).

Perlakuan B: 75\% Pakan alami Microworm (Panagrellus redivivus) dan 25\% Pakan alami Nauplius Artemia

Perlakuan C: 50\% Pakan alami Microworm (Panagrellus redivivus) dan 50\% Pakan alami Nauplius Artemia

Perlakuan D : 25\% Pakan alami Microworm (Panagrellus redivivus) dan Pakan alami $75 \%$ Nauplius Artemia

Perlakuan E: 100\% Pakan alami Nauplius Artemia 
Tabel 1. Perlakuan dan ulangan

\begin{tabular}{clllll}
\hline Ulangan & \multicolumn{5}{c}{ Perlakuan } \\
\cline { 2 - 6 } & A & B & C & D & E \\
\hline 1 & A1 & B1 & C1 & D1 & E1 \\
2 & A2 & B2 & C2 & D2 & E2 \\
3 & A3 & B3 & C3 & D3 & E3 \\
4 & A4 & B4 & C4 & D4 & E4 \\
5 & A5 & B5 & C5 & D5 & E5 \\
\hline
\end{tabular}

\section{Prosedur Penelitian \\ Persiapan Wadah Uji}

Wadah yang digunakan pada penelitian ini adalah ember ukuran diameter atas $30 \mathrm{~cm}$, diameter bawah $20 \mathrm{~cm}$, tinggi 21 $\mathrm{cm}$. Ember yang digunakan disterilisasikan terlebih dahulu kemudian di isi air 4 liter dari wadah uji, lalu diendapkan selama 24 jam. Kepadatan optimum yang terbaik ikan Cupang (Betta sp.) adalah 4 ekor/liter (SNI: 7777:2013).

\section{Ikan Uji}

Sampel ikan Cupang (Betta sp.) yang digunakan umur 10 hari yaitu saat kuning telur terserap sempurna (Valentine et al, 2013). Benih ikan Cupang didapat dari hasil pemijahan satu pasang ikan Cupang (Betta sp.). Benih yang dipilih pada umur 3 hari saat kuning telur terserap sempurna (Valentine et al, 2013) normal dan sehat dengan ukuran panjang rata-rata tubuh $3 \mathrm{~mm}$ dan bobot rata-rata. 0,00456g. Selanjutnya sampel ikan digunakan pada umur 10 hari. Ikan Cupang (Betta sp.) yang digunakan dalam penelitian adalah jenis ikan Cupang HMPK (Halfmoon Plakat).

\section{Persiapan Pakan}

Pakan yang digunakan selama penelitian berupa pakan alami, Microworm (Panagrellus redivivus) dan Nauplius Artemia. Jumlah pakan yang diberikan sebanyak 30\% dari berat total benih yang dipelihara. Pemberian pakan berdasarkan biomassa yakni pemberian pakan dilakukan berdasarkan bobot total ikan hasil sampling dikalikan total ikan dan dikali 30\%. Pemberian pakan 1 kali sehari pada pagi hari pukul 07.00 WIB pada masing-masing perlakuan. Pemeliharaan ikan dilakukan selama 40 hari dan sampling setiap 10 hari.

\section{Pengelolaan Air}

Pemantauan kualitas air dilakukan sebanyak 5 kali dalam 10 hari sekali, untuk mengetahui gambaran kualitas air secara umum. Parameter kualitas lingkungan budidaya yang diukur adalah suhu, $\mathrm{pH}, \mathrm{DO}$, dan kadar Nitrat. Kadar Nitrat diukur pada saat akhir pemeliharaan.

\section{Parameter Pengamatan \\ Analisis Nutrisi Pakan}

Analisis nutrisi pakan adalah suatu metode untuk mengidentifikasi kandungan nutrisi pada suatu zat makanan dari bahan pakan. Analisis nutrisi pakan dilakukan terhadap pakan percobaan untuk melihat nutrien pakan yang dapat menghasilkan energi (kkal), yaitu: Kandungan protein, kandungan lemak, kandungan energi dalam pakan dan kandungan serat kasar.

\section{Laju Pertumbuhan Harian}

Pengukuran laju pertumbuhan bobot dan panjang harian dilakukan setiap 10 hari sekali. Laju pertumbuhan spesifik dapat dihitung berdasarkan rumus (Verdegem dan Edding, 2010). 


$$
\mathrm{SGR}=\frac{\ln W \mathrm{t}-\ln \mathrm{W} 0}{t_{1}-t_{0}} \times 100 \%
$$

keterangan:

$$
\begin{aligned}
& \text { SGR = Laju Pertumbuhan Harian (\%) } \\
& \mathrm{Wt}=\text { Bobot rata-rata ikan di akhir } \\
& \text { pemeliharaan (ekor) } \\
& \mathrm{W} 0=\text { Bobot rata-rata ikan di awal } \\
& \text { pemeliharaan (ekor) } \\
& \mathrm{t}=\text { Lama waktu pemeliharaan (hari) } \\
& \text { Pertumbuhan panjang harian } \\
& \text { dihitung dengan menggunakan rumus } \\
& \text { menurut Busacker et al, (1990) diacu oleh } \\
& \text { Widiyiantara (2009) sebagai berikut: } \\
& \mathbf{P h}=[(\ln \mathrm{Lt}-\ln \mathrm{L} 0) / \mathrm{t}] \times 100 \%
\end{aligned}
$$

\section{Laju Pertumbuhan Mutlak}

Indikator pertumbuhan yang digunakan adalah pertambahan biomassa mutlak ikan yang dihitung berdasarkan rumus Zonneveld (1991):

$$
\mathrm{B}=\boldsymbol{W} \boldsymbol{t}-\boldsymbol{W o}
$$

Keterangan :

$\mathrm{B}=$ Pertambahan biomassa mutlak ikan uji (g).

$\mathrm{Wt}=$ Biomassa ikan uji pada akhir percobaan $(\mathrm{g})$.

Wo = Biomassa ikan uji pada awal percobaan $(\mathrm{g})$.

Sedangkan untuk perhitungan pertumbuhan panjang mutlak dapat dihitung dengan menggunakan rumus Zonneveld (1991) yaitu :

Keterangan :

$$
L m=L t-L o
$$

$\mathrm{Lm}=$ Pertumbuhan.

Lt $\quad=$ Panjang akhir $(\mathrm{cm})$.

Lo = Panjang awal $(\mathrm{cm})$.

\section{Tingkat Kelangsungan Hidup}

Pengamatan terhadap kelangsungan hidup ikan uji dilakukan setiap hari dengan cara menghitung jumlah ikan uji yang hidup sampai akhir penelitian. Secara umum kelangsungan hidup dapat di hitung dengan rumus Effendie (1997).

Keterangan:

$$
S R=\frac{N t}{N o} \times 100 \%
$$

SR : Persentase kelangsungan hidup ikan (\%) $\mathrm{Nt}$ : Jumlah ikan uji yang hidup pada akhir penelitian (ekor)

No : Jumlah ikan uji pada awal penelitian (ekor)

\section{Analisis Ekonomi}

Hasil yang terbaik dinilai dengan cara membandingkan jumlah ekor dalam setiap perlakuan (5 Ulangan) dikalikan dengan nilai jual setiap perekor benih Cupang (Betta sp.) yaitu Rp. 2830 rupiah/ekor. Biaya perawatan Rp. 19.200. Untuk menghitung pendapatan bersih usaha digunakan rumus menurut Yunita (2017).

$$
\pi=\mathrm{TR}-\mathrm{TC}
$$

Keterangan:

$\pi$ : Pendapatan Bersih

TR: Pendapatan Kotor

TC: Biaya Total

\section{HASIL DAN PEMBAHASAN}

\section{Analisis Nutrisi Pakan}

Hasil analisis nutrisi pakan dalam

bobot kering, penelitian substitusi

penggunaan Nauplius Artemia dengan

Microworm (Panagrellus redivivus) pada Tabel 2.

Berdasarkan hasil uji proksimat pakan alami Microworm (Panagrellus redivivus) kandungan Protein 16,37\%, Lemak 6,80\%, Energi $4565 \mathrm{Kcal} / \mathrm{kg}$ dan kandungan Serat 2,41\%. Pakan alami Nauplius Artemia dengan kandungan Protein 66,01\%, Lemak 3,26\%, Energi 2995 $\mathrm{Kcal} / \mathrm{kg}$ dan kandungan Serat 8,40\%. Beberapa komponen nutrisi yang penting bagi pertumbuhan ikan adalah protein, lemak, energi dalam pakan dan serat. 
Tabel 2. Hasil uji proksimat

\begin{tabular}{lcccc}
\hline \multicolumn{4}{c}{ Hasil analisis nutrisi pakan dalam bobot kering } & \\
\hline Perlakuan & $\begin{array}{c}\text { Protein } \\
\%\end{array}$ & $\begin{array}{c}\text { Lemak } \\
\%\end{array}$ & $\begin{array}{c}\text { Energi } \\
\text { Kcal / kg }\end{array}$ & $\begin{array}{c}\text { Serat } \\
\%\end{array}$ \\
\hline Microworm (Panagrellus redivivus) & 16,37 & 6,80 & 4565 & 2,41 \\
\hline Nauplius Artemia & 66,01 & 3.26 & 2995 & 8,40
\end{tabular}

Sumber: Balai Penelitian Ternak Laboratorium, (Bogor 2020)

Hasil analisis nutrisi pakan dalam bobot kering Microworm (Panagrellus redivivus) protein $16,37 \%$, lemak $6,80 \%$ dan Nauplius Artemia protein 66,01\%, lemak $3.26 \%$. Berbeda dengan studi Affandi et al (2019), menyatakan protein Microworm (Panagrellus redivivus) sebesar 50\%. Sedangkan pernyataan Uribe et al (2018), menyatakan untuk nutrisi Microworm (Panagrellus redivivus) protein 44,22\%, lemak 11,31\% dan Nauplius Artemia protein $57,26 \%$, lemak 16,21\%.

\section{Laju Pertumbuhan Harian}

Hasil rata-rata jumlah pertumbuhan harian dari hari ke $10-40$ hari larva ikan Cupang (Betta sp.) berdasarkan hasil penelitian dilakukan dalam percobaan perlakuan pakan yang disubstitusikan penggunaan Nauplius Artemia dengan Microworm (Panagrellus redivivus).

Berdasarkan hasil uji diperoleh nilai signifikan 0,469 yang berarti > 0,05 maka H0 diterima dan $\mathrm{H} 1$ ditolak. Hal ini menunjukan bahwa pertumbuhan panjang harian tidak ada pengaruh substitusi penggunaan Nauplius Artemia dengan Microworm (Panagrellus redivivus) terhadap pertumbuhan panjang harian larva ikan Cupang (Betta sp.). Hasil uji laju pertumbuhan bobot harian diperoleh nilai signifikan 0,323 yang berarti $>0,05$ maka $\mathrm{H} 0$ diterima dan $\mathrm{H} 1$ ditolak. Hal ini menunjukan bahwa pertumbuhan bobot harian tidak ada pengaruh substitusi penggunaan Nauplius Artemia dengan Microworm (Panagrellus redivivus) terhadap pertumbuhan bobot harian larva ikan Cupang (Betta sp.). Perlakuan masing-masing mendapatkan rata-rata Pertumbuhan panjang harian A $(73,6666 \%), B \quad(72,3333 \%), \quad$ C $(71,9167 \%)$, D $(71,4167 \%)$, dan E (70,6667\%). Laju pertumbuhan bobot harian rata-rata sekitar A $(3,1600 \%), \mathrm{B}(3,1320 \%), \mathrm{C}$ $(3,1380 \%)$, D $(3,1060 \%)$, dan E $(3,0840 \%)$.

Tabel 3. Pertumbuhan panjang dan bobot larva ikan cupang (Betta sp.) harian

\begin{tabular}{ccc}
\hline Perlakuan & $\begin{array}{c}\text { Laju pertumbuhan } \\
\text { panjang harian }(\%)\end{array}$ & $\begin{array}{c}\text { Laju pertumbuhan } \\
\text { bobot harian }(\%)\end{array}$ \\
\hline A & $73,66 \pm 1,078^{\mathrm{a}}$ & $3,16 \pm 0,036^{\mathrm{a}}$ \\
B & $72,33 \pm 3,18^{\mathrm{a}}$ & $3,13 \pm 0,024^{\mathrm{a}}$ \\
C & $71,91 \pm 2,96^{\mathrm{a}}$ & $3,13 \pm 0,10^{\mathrm{a}}$ \\
D & $71,41 \pm 3,22^{\mathrm{a}}$ & $3,10 \pm 0,05^{\mathrm{a}}$ \\
E & $70,66 \pm 1,83^{\mathrm{a}}$ & $3,08 \pm 0,03^{\mathrm{a}}$
\end{tabular}

Keterangan : Nilai yang diikuti huruf kecil superscript yang sama menunjukan pengaruh yang tidak berbeda nyata $(\mathrm{P}>0,05)$. 


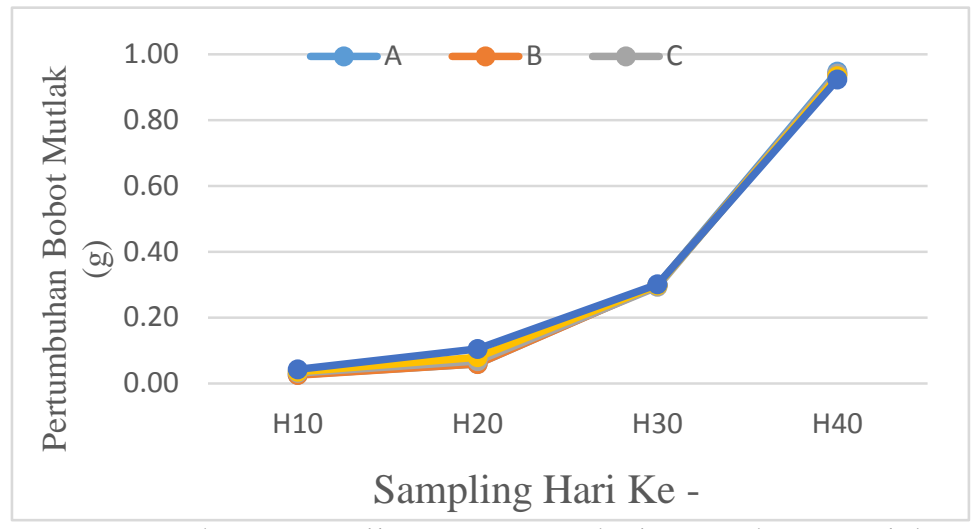

Gambar 1. Hasil Laju Pertumbuhan Bobot Mutlak

\section{Laju Pertumbuhan Bobot Mutlak}

Hasil rata-rata laju pertumbuhan bobot larva ikan Cupang berdasarkan hasil penelitian substitusi penggunaan Nauplius Artemia dengan Microworm (Panagrellus redivivus) terhadap pertumbuhan bobot mutlak larva ikan Cupang (Betta sp.).

Pada Gambar 5 menunjukan bahwa pertumbuhan bobot mutlak tertinggi di hari ke 40 terdapat pada perlakuan A $(0,948 \mathrm{~g}), \mathrm{B}$ $(0,940 \mathrm{~g}), \quad \mathrm{C} \quad(0,942 \mathrm{~g}), \quad \mathrm{D} \quad(0,934 \mathrm{~g})$ dan pertumbuhan bobot mutlak terendah didapat oleh perlakuan E $(0,924 \mathrm{~g})$. Hasil Uji Lanjut Laju Pertumbuhan Bobot Mutlak Ikan Cupang (Betta sp.) pada Tabel 4.
Berdasarkan hasil uji (Lampiran 2) diperoleh nilai signifikan 0,335 yang berarti $>0,05$, maka H0 diterima dan H1 ditolak. Tidak ada pengaruh substitusi penggunaan Nauplius Artemia dengan Microworm (Panagrellus redivinus) terhadap pertumbuhan bobot mutlak larva ikan Cupang (Betta sp.).

Laju pertumbuhan panjang mutlak larva ikan Cupang berdasarkan hasil penelitian substitusi penggunaan Nauplius Artemia dengan Microworm (Panagrellus redivivus) terhadap pertumbuhan panjang mutlak larva ikan Cupang pada Gambar 6. Hasil Laju Pertumbuhan Panjang Mutlak Larva Ikan Cupang (Betta sp.).

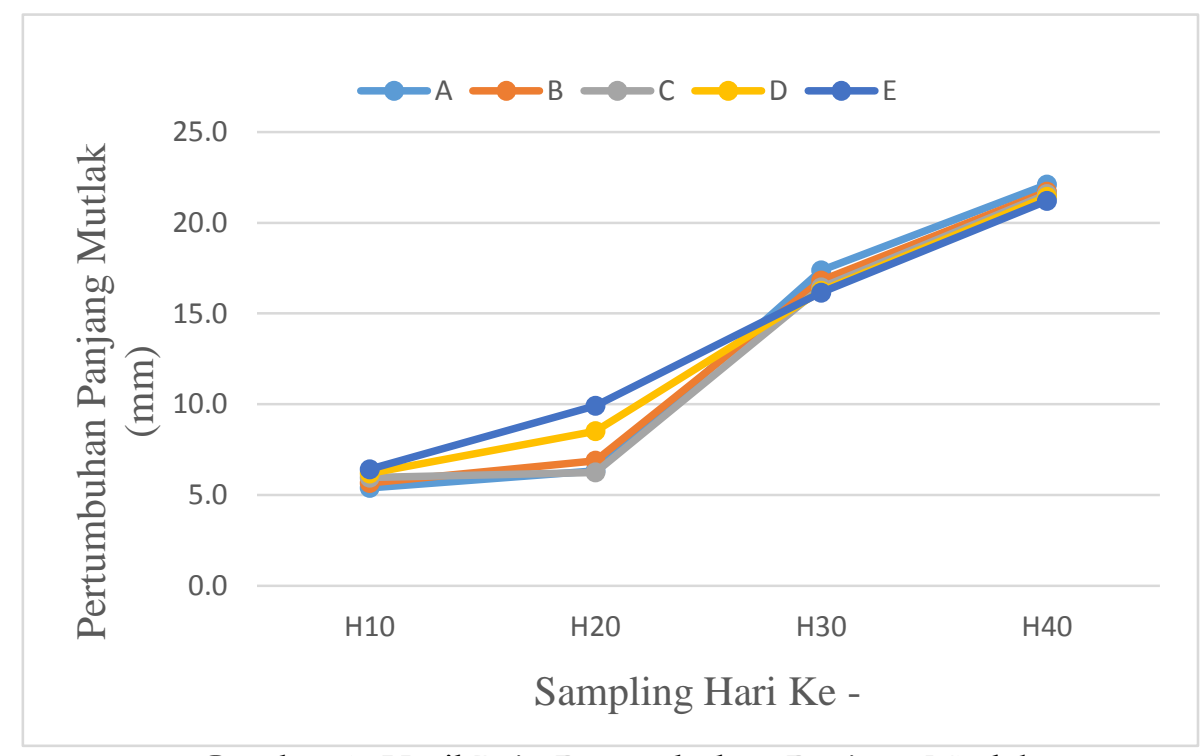

Gambar 2. Hasil Laju Pertumbuhan Panjang Mutlak 
Tabel 4. Pertumbuhan bobot mutlak larva ikan Cupang (Betta sp.)

\begin{tabular}{ccc}
\hline No & Perlakuan & Pertumbuhan Bobot (g/ekor) \\
\hline 1. & A &, $9480 \pm, 01304^{\mathrm{a}}$ \\
2. & B &, $9400 \pm, 00707^{\mathrm{a}}$ \\
3. & C &, $9420 \pm, 03271^{\mathrm{a}}$ \\
4. & $\mathrm{D}$ &, $9340 \pm, 01673^{\mathrm{a}}$ \\
5. & $\mathrm{E}$ &, $9240 \pm, 01140^{\mathrm{a}}$
\end{tabular}

Keterangan: Nilai yang diikuti huruf kecil superscript yang sama menunjukan pengaruh yang tidak berbeda nyata $(\mathrm{P}>0,05)$.

Berdasarkan hasil uji (Lampiran 2) diperoleh nilai signifikan 0,470 yang berarti $>0,05$, maka H0 diterima dan H1 ditolak. Tidak ada pengaruh substitusi penggunaan Nauplius Artemia dengan Microworm (Panagrellus redivivus) terhadap pertumbuhan panjang mutlak larva ikan Cupang (Betta sp.).

Berdasarkan hal ini diduga pada perlakuan A larva ikan Cupang (Betta sp.) dapat tumbuh lebih baik saat larva berumur di atas 20 hari, karena larva ikan Cupang (Betta sp.) mengkonsumsi pakan dengan nutrisi sesuai kebutuhan untuk pertumbuhannya. Perlakuan E memberikan pertumbuhan yang rendah pada hasil akhir, diduga nutrisi lemak yang rendah dan serat kasar yang tinggi. Ukuran dan bertambahnya umur ikan Cupang (Betta sp.) salah satu faktor penghambatan laju pertumbuhan larva ikan Cupang (Betta sp.).

Tingkat Kelangsungan Hidup Hasil rata-rata tingkat kelangsungan hidup larva ikan Cupang (Betta sp.) berdasarkan hasil penelitian substitusi penggunaan Nauplius Artemia dengan Microworm (Panagrellus redivivus).

Tabel 5. Pertumbuhan panjang mutlak larva ikan Cupang ( Betta sp.)

\begin{tabular}{ccc}
\hline No & Perlakuan & Pertumbuhan Panjang Mutlak $(\mathrm{mm})$ \\
\hline 1. & A & $22,1020 \pm, 32568^{\mathrm{a}}$ \\
2. & B & $21,7010 \pm, 95630^{\mathrm{a}}$ \\
3. & C & $21,5760 \pm, 89170^{\mathrm{a}}$ \\
4. & D & $21,4260 \pm, 96754^{\mathrm{a}}$ \\
5. & E & $21,2020 \pm, 55052^{\mathrm{a}}$
\end{tabular}

Keterangan : Nilai yang diikuti huruf kecil superscript yang sama menunjukan pengaruh yang tidak berbeda nyata $(\mathrm{P}>0,05)$. 


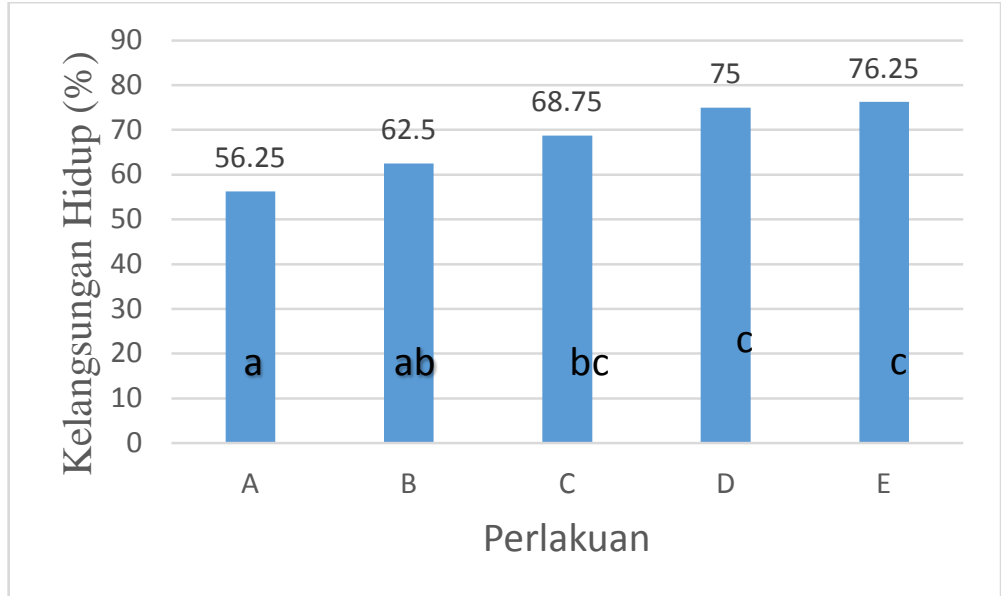

Gambar 3. Hasil tingkat kelangsungan hidup

Keterangan : (nilai yang diikuti huruf superscript berbeda menunjukan pengaruh berbeda nyata $\mathrm{P}<0,05)$.

Hasil tingkat kelangsungan hidup menunjukan tingkat kelangsungan hidup tertinggi diperoleh pada perlakuan $\mathrm{E}$ yang diberi pakan Nauplius Artemia (100\%) dengan nilai sebesar $76,25 \%$, perlakuan D yang diberi pakan (Nauplius Artemia 75\% + 25 Microworm, Panagrellus redivivus) dengan nilai sebesar $75 \%$, perlakuan $C$ yang diberi pakan (Microworm, Panagrellus redivivus 50\% $+50 \%$ Nauplius Artemia) dengan nilai 68,75\%, perlakuan B yang diberi pakan (Microworm, Panagrellus redivivus $75 \%+25 \%$ Nauplius Artemia) dengan nilai $62,50 \%$, dan tingkat kelangsungan hidup terendah pada perlakuan A yang diberi pakan Microworm (Panagrellus redivivus) $100 \%$ dengan nilai sebesar 56,25\%.

Berdasarkan hasil uji (Lampiran 2) diperoleh nilai signifikan 0,000 yang berarti $<$ 0,05, maka H0 ditolak dan H1 diterima. Ada pengaruh substitusi penggunaan Nauplius Artemia dengan Microworm (Panagrellus redivivus) terhadap kelangsungan hidup larva ikan Cupang (Betta sp.). Berdasarkan dari hasil studi Kaseger et al (2019) tingkat kelangsungan larva ikan Cupang (Betta sp.) perlakuan pemberian dengan Alona sp. 56\%, perlakuan dengan pemberian rebusan kuning telur 26\%, sedangkan perlakuan dengan pemberian pakan komersil $0 \%$. Berdasarkan hal ini penelitian pemberian pakan Microworm
(Panagrellus redivivus) dan Nauplius Artemia lebih baik dengan kelangsungan hidup larva ikan Cupang (Betta sp.) 56,25\% - 76,25\%.

Tingkat kelangsungan hidup larva ikan Cupang (Betta sp.) setelah perlakuan selama 40 hari dengan nilai rata-rata persentase tertinggi terdapat pada perlakuan E (100\% Nauplius Artemia) dan tingkat kelangsungan hidup terendah terdapat pada perlakuan A (100\% Microworm (Panagrellus redivivus)). Mulyani et al (2014), menyatakan bahwa tingkat kelangsungan hidup $>50 \%$ tergolong baik, tingkat kelangsungan hidup $30-50 \%$ tergolong sedang dan kurang dari $30 \%$ tidak baik. Perbedaan tingkat kelangsungan hidup pada tiap perlakuan yang disebabkan oleh faktor biotik dan abiotik yang mempengaruhi tinggi rendahnya tingkat kelangsungan suatu organisme. Faktor biotik antara lain kepadatan populasi, umur dan kemampuan organisme dengan lingkungan. Sedangkan faktor abiotik seperti suhu, oksigen terlarut, $\mathrm{pH}$ dan amonia (Yurisma dan Heltonika, 2010).

\section{Kualitas Air}

Hasil pengukuran kualitas air menunjukan bahwa faktor fisik, kimia media kultur seperti Oksigen terlarut, Suhu, $\mathrm{pH}$, masih dalam kisaran yang baik untuk kelangsungan hidup larva ikan Cupang (Betta sp.). 
Tabel 6. Kualitas air

\begin{tabular}{llcc}
\hline No & \multicolumn{1}{c}{ Parameter } & Hasil & Referensi \\
\hline 1 & DO & $2,3-5,7 \mathrm{mg} / \mathrm{L}$ & $3 \mathrm{mg} / \mathrm{L}$ (Ladyescha et al, 2015) \\
2 & Suhu ${ }^{\circ} \mathrm{C}$ & $25-28{ }^{\circ} \mathrm{C}$ & $24-30{ }^{\circ} \mathrm{C}$ (Ladyescha et al, 2015) \\
3 & $\mathrm{pH}$ & $7,4-8,1$ & $6,5-9,0$ (SITH-ITB, 2009) \\
4 & Nitrat & $12,5-100 \mathrm{mg} / \mathrm{L}$ & $<50 \mathrm{mg} / \mathrm{L}$ (Kroupova et al. 2005) \\
\hline
\end{tabular}

Hasil pengukuran kualitas air pada Tabel 6 menunjukan bahwa faktor fisik, kimia media kultur seperti Oksigen terlarut, Suhu, $\mathrm{pH}$, masih dalam kisaran yang baik untuk kelangsungan hidup larva ikan Cupang (Betta sp.). Perubahan suhu rata-rata media kultur selama penelitian yaitu $25-28{ }^{\circ} \mathrm{C}$, nilai DO selama pemeliharaan berkisar antara 2,3 - 5,7 mg/L. Kisaran $\mathrm{pH}$ selama penelitian adalah 7,4-8,1, sedangkan untuk kisaran Nitrat 12,5 - $100 \mathrm{mg} / \mathrm{L}$. Ikan Cupang (Betta sp.) dapat hidup dalam air yang memiliki kandungan oksigen minimal 3 $\mathrm{mg} / \mathrm{L}, \mathrm{pH}$ 6,5 - 9,0, tingkat Nitrat terlarut maksimal $50 \mathrm{mg} / \mathrm{L}$. DO menunjukkan jumlah oksigen terlarut dalam air.

\section{Analisis Ekonomi}

Hasil penelitian larva ikan Cupang (Betta sp.) hubungan antara padat tebar, kelangsungan hidup, dan nilai ekonomi pada penelitian ini. Perhitungan ekonomi pada lampiran 6. Analisis ekonomi dalam Tabel 7 sebagai berikut:

Berdasarkan hasil analisis ekonomi di atas nilai pendapatan yaitu (jumlah ikan akhir
@Rp. 2.830,-) dan nilai biaya total yaitu (biaya perawatan + biaya harga pakan) sehingga di dapat Keuntungan = (Pendapatan - Biaya total). Keuntungan perlakuan A dengan jumlah ikan akhir 53 @Rp. 2.830,- di kurangi (biaya perawatan Rp. 19.200,- + biaya harga pakan Rp. 25.207,-) sehingga didapat keuntungan sebesar Rp. 105.583,-. Tingkat kelangsungan hidup tinggi dan biaya pakan yang rendah dapat mempengaruhi hasil keuntungan yang tinggi. Perlakuan A biaya pakan selama 40 hari Rp 3.784 - Rp 4.827 dari per biomassa ikan dengan menghabiskan Microworm (Panagrellus redivivus) 7,202g dengan biaya $1 \mathrm{~g}$ Panagrellus Rp. 350. Perlakuan E biaya pakan selama 40 hari Rp 23.928 - Rp 31.822 dengan menghabiskan Nauplius Artemia 9,654g dengan biaya $1 \mathrm{~g}$ Nauplius Artemia Rp. 1.730. Jangka waktu penelitian selama 40 hari, pada perlakuan dengan pemberian Microworm (Panagrellus redivivus) selama penelitian memerlukan 19,76g sedangkan dengan pemberian Nauplius Artemia menghabiskan 23,21g.

Tabel 7. Analisis Ekonomi

\begin{tabular}{ccccccccc}
\hline PERLAKUAN & $\begin{array}{c}\text { JUMLAH } \\
\text { IKAN } \\
\text { (ekor) }\end{array}$ & $\begin{array}{c}\text { KELANGSUNGan } \\
\text { HIDUP (\%) }\end{array}$ & $\begin{array}{c}\text { JUMLAH } \\
\text { IKAN } \\
\text { AKHIR }\end{array}$ & $\begin{array}{c}\text { HARGa } \\
\text { (Rp/Ekor) }\end{array}$ & $\begin{array}{c}\text { PENDAPATAN } \\
(\mathrm{Rp})\end{array}$ & $\begin{array}{c}\text { PERAWATAN } \\
\text { (Rp) }\end{array}$ & $\begin{array}{c}\text { HARGA } \\
\text { PAKAN }\end{array}$ & $\begin{array}{c}\text { KEUNTUNGAN } \\
\text { (Rp) }\end{array}$ \\
\hline A & 96 & 56,25 & 53 & 2830 & 149990 & 19200 & 25207 & 105583 \\
B & 96 & 62,50 & 58 & 2830 & 164140 & 19200 & 54159 & 90781 \\
C & 96 & 68,75 & 64 & 2830 & 181120 & 19200 & 88649 & 73271 \\
D & 96 & 75 & 71 & 2830 & 200930 & 19200 & 135732 & 45998 \\
E & 96 & 76,25 & 72 & 2830 & 203760 & 19200 & 167017 & 17543 \\
\hline
\end{tabular}




\section{KESIMPULAN}

Kesimpulan yang diperoleh dari penelitian ini adalah sebagai berikut:

1) Pemberian jenis pakan alami Microworm (Panagrellus redivivus) dan Nauplius Artemia dapat meningkatkan pertumbuhan bobot dan pertumbuhan panjang pada larva ikan Cupang (Betta sp.). Berdasarkan hasil uji diperoleh nilai $\mathrm{P}>0,05$, maka $\mathrm{H} 0$ diterima dan H1 ditolak. Tidak ada pengaruh substitusi penggunaan Nauplius Artemia dengan Microworm (Panagrellus redivivus) terhadap pertumbuhan larva ikan Cupang (Betta sp.).

2) Tingkat kelangsungan hidup tertinggi diperoleh pada perlakuan $\mathrm{E}$ yang diberi pakan Nauplius Artemia (100\%) dengan nilai sebesar $76,25 \%$, dan tingkat kelangsungan hidup terendah terdapat pada perlakuan A yang diberi pakan Microworm (Panagrellus redivivus) 100\% dengan nilai sebesar 56,25\%. Berdasarkan hasil uji diperoleh nilai signifikan 0,000 yang berarti $<0,05$, maka $\mathrm{H} 0$ ditolak dan H1 diterima. Ada pengaruh substitusi penggunaan Nauplius Artemia dengan Microworm (Panagrellus redivivus) Terhadap Kelangsungan Hidup Larva Ikan Cupang (Betta sp.).

3) Perlakuan E diberi pakan Nauplius Artemia $(100 \%)$ merupakan pakan terbaik untuk kelangsungan hidup larva ikan Cupang (Betta sp.) dengan nilai sebesar 76,25\% namun dengan biaya pakan yang tinggi berdampak pada keuntungan yang lebih kecil (Rp. 17.543,-) dibandingkan dengan perlakuan A yang diberi pakan Microworm (Panagrellus redivivus) $100 \%$ dengan keuntungan (Rp.105.583,-). Berdasarkan analisis ekonomi perlakuan A berupa 100\% Microworm (Panagrellus redivivus) menjadi pemberian pakan yang diunggulkan untuk pakan alternatif, karena menghasilkan keuntungan sebesar Rp. 105.583,- dan biaya pakan yang rendah $1 \mathrm{~g}$ Microworm (Panagrellus redivivus)
Rp. 350 dibandingkan dengan $1 \mathrm{~g}$ Nauplius Artemia Rp 1.730.

\section{DAFTAR PUSTAKA}

BKIPM. 2021. Ikan Cupang dari Batam Jangkau Pasar Domestik dan Ekspor. Badan Karantina Ikan, Pengendalian Mutu Dan Keamanan Hasil Perikanan.

bttps:/ / kekp.go.id/bkipm/artikel/27326ikan-cupang-dari-batam-jangkau-pasardomestik-dan-ekspor.

Effendi M.I 1997. Biologi Perairan. Yayasan Pustaka Nusantara.

Irama. R, 2017. Pengaruh persentase cacing renik (Panagrellus redivivus) Terhadap Pertumbuhan dan Kelangsungan Hidup Larva Ikan gurami (osphronemus goramy). Skripsi Universitas Muhammadiyah Pontianak.

Kroupova H, Machova J, Svobodova Z. (2005). Nitrite influence on fish: a review. Veterinarni Medicina. 50 (11): 461-471.

Ladyescha, D., Nugroho, R. A. and Dharma, B. (2015). Ujii Efektivitas Ekstrak Cair Daun Ketapang (Terminalia catappa Linn.) sebagai Antibakteri terhadap Ikan Cupang (Betta sp..) yang Diinfeksi Bakteri Salmonella enterica serovar Typhi, pp. 27-34.

Putra, A. N. 2015. Metabolisme Basal Pada Ikan. Jurnal Perikanan dan Kelautan Vol. 5 No. 2 : 57-65. Desember 2015.

SITH-ITB. 2009. Teknologi Pengelolaan Kualitas Air, Progam Alih Jenjang D4 Bidang Akuakultur. SITH, ITBVEDCA-SEAMOLEC.

Simbolon, A. O., \& Usman S. 2018. Pengaruh Pemberian Pakan Alami yang Berbeda terhadap Pertumbuhan 
dan Kelangsungan Hidup Larva Ikan Cupang Hias (Betta sp.lendens). Growth, Larvae (Betta sp.lendens), Tubifex sp., Daphia sp., Infusoria. Jurnal Fakultas Pertanian Universitas Sumatera Utara, Medan, Indonesia. 2018.

SNI 7777:2013, Produksi ikan cupang hias (Betta sp.lendens).

Sorgeloos, P. and Lavens, P. 1996. Manual on Production and Use of Life Food for Aquaculture. FAO Fisheries Technical Paper. Center University of Ghent. Belgium.

Susanto, B., Wardoyo, Ismi, S., Sugama, K., Wahyuadi, K. 2000. Evaluasi Keragaan Dan Kualitas Artemia Produksi Lokal Dan Impor. Jurnal Penelitian Perikanan Indonesia volume 6 Nomor 1 Tahurt 2000.

Syaputra, R., Santoso, L., Tarsim. 2018. Pengaruh Penambahan Tepung Daun Gamal (Gliricidia sepium) pada Pakan Buatan terhadap Sintasan dan
Pertumbuhan Ikan Gurami (Osphronemus gouramy). Jurnal Sains Teknologi Akuakultur, 2(1) : 1-11

Verdegem, $\mathrm{M}$ and E. Edding, 2010. Aquaculture Production Sistem. Lectur Note. Aquaculture And Fisheries Wagenigem University.

Widiyantara, G. B. 2009. Kinerja Produksi Pendederan Lele Sangkuriang (Clarias Sp) Melalui Penerapan Teknologi Pergantian Air 50\%, 100\%, Dan 150\% Per Hari . Program Studi Teknologi Dan Manajemen Perikanan Budidaya. Fakultas Perikanan Dan Ilmu Kelautan. Institut Pertanian Bogor.

Yunita, I. 2017. Analisis Kelayakan Usaha Dodol Pulut di Desa Puloh Kecamatan Peusangan Kabupaten Bireuen. Jurnal S. Pertanian 1 (10): 826-836.

Zonneveld. 1991. Prinsip-Prinsip Budidaya Ikan. Jakarta. PT.Gramedia Pustaka Utama. 